\title{
Regional Trade Integration and Multinational Firm Strategies
}

\section{Citation}

Antras, Pol, and C. Fritz Foley. 2009. Regional trade integration and multinational firm strategies. Nber Working Paper No. 14891.

\section{Published Version}

http://www.nber.org/papers/w14891

\section{Permanent link}

http://nrs.harvard.edu/urn-3:HUL.InstRepos:3374522

\section{Terms of Use}

This article was downloaded from Harvard University's DASH repository, and is made available under the terms and conditions applicable to Open Access Policy Articles, as set forth at http:// nrs.harvard.edu/urn-3:HUL.InstRepos:dash.current.terms-of-use\#OAP

\section{Share Your Story}

The Harvard community has made this article openly available.

Please share how this access benefits you. Submit a story.

Accessibility 


\title{
Regional Trade Integration and Multinational Firm Strategies
}

\author{
Pol Antràs and C. Fritz Foley*
}

April 2009

\begin{abstract}
This paper analyzes the effects of the formation of a regional trade agreement on the level and nature of multinational firm activity. We examine aggregate data that captures the response of U.S. multinational firms to the formation of the ASEAN free trade agreement. Observed patterns guide the development of a model in which heterogeneous firms from a source country decide how to serve two foreign markets. Following a reduction in tariffs on trade between the two foreign countries, the model predicts growth in the number of source-country firms engaging in foreign direct investment, growth in the size of affiliates that are active in reforming countries both before and after the tariff reduction, and an increase in the extent to which the sales of affiliates in reforming countries are directed towards other reforming countries. Analysis of firm-level responses to the creation of the ASEAN free trade agreement yields results that are consistent with these predictions.
\end{abstract}

\footnotetext{
*Harvard University and NBER; Harvard Business School and NBER. This paper was prepared for the Workshop on "Quantifying the Costs and Benefits of Regional Economic Integration," held on January 19-20, 2009 in Hong Kong. The statistical analysis of firm-level data on U.S. multinational companies was conducted at the Bureau of Economic Analysis, U.S. Department of Commerce under arrangements that maintain legal confidentiality requirements. The views expressed are those of the authors and do not reflect official positions of the U.S. Department of Commerce. We are grateful to Eduardo Morales for superb research assistance and to Robert Barro, Elhanan Helpman, Jong-Wha Lee, Emanuel Ornelas, Bill Zeile, and seminar participants at Harvard and the Asian Development Bank for helpful suggestions.
} 


\section{Introduction}

Regional trade agreements significantly impact the structure of international trade flows. Existing research emphasizes the costs and benefits inherent in the trade creation and trade diversion effects of these agreements and considers if they generate incentives for trading partners to promote or thwart the development of an open multilateral trading system. Most of the existing analyses fail to consider the effect of regional trade agreements on patterns of foreign direct investment. In this paper, we study these effects.

Our empirical analysis focuses on the behavior of multinational firms based in the U.S. around the time of a single event, the signing of the ASEAN FTA (AFTA) in January of 1992. We begin by reviewing aggregate data on U.S. multinationals and then use some broad trends in those data to guide the development of a model of how multinationals based outside of a region respond to the formation of a free trade agreement in the region. This model builds on the work of Helpman, Melitz and Yeaple (2004), and incorporates firm-level heterogeneity to generate predictions of how lower regional trade costs affect the intensive and extensive margins of foreign direct investor activity. In addition to high-

lighting effects on levels of activity, the theory also delivers implications for the share of multinational affiliate activity directed towards serving different markets. Departing from previous approaches that only used aggregate data, we test these predictions using the firm-level results of the benchmark Survey of U.S. Direct Investment Abroad conducted by the Bureau of Economic Analysis.

The ASEAN agreement of 1992 was signed by six countries: Brunei, Indonesia, Malaysia, Philippines, Singapore and Thailand. In subsequent years, four additional countries joined AFTA; Vietnam in 1995, Laos and Myanmar in 1997, and Cambodia in 1999. The original agreement outlined a program of progressive tariff reductions to be carried out through 2008, but the member countries subsequently decided to accelerate reforms and make AFTA fully operational on January 1, 2003. We analyze data on U.S. multinational operations in ASEAN and other Asian countries in the 1989 and 1994 benchmark survey years. Doing so allows for a comparison of the changing structure of multinational activity in countries that signed AFTA in 1992 and in other similar countries. Our tests therefore attempt to rule out the possibility that changes in activity in ASEAN countries are driven by factors unrelated to AFTA like technological shocks or other general drivers of U.S. multinational expansion. While ASEAN tariff reductions continued after 1994, substantial progress had been made by that time, and it is plausible that U.S. multinationals would have started responding to the process of regional trade integration shortly after the signing of the agreement in 1992. Although the results are robust to analyzing 
longer time frames, our main analysis does not use data from the 1999 benchmark survey because a subset of AFTA's signing countries experienced a severe financial crisis in 1997, which affected FDI into the region for reasons quite distinct from those analyzed here.

Section 2 of the paper describes broad patterns regarding the operations of U.S. multinational firms in Asia in 1989 and 1994. The data indicate a surge in the level of activity in ASEAN countries around the time of the formation of AFTA that exceeds levels of growth in other Asian countries. Analysis of growth among affiliates that were active both before and after the creation of AFTA and net entry of affiliates reveals that both types of growth contributed to the higher levels of relative expansion in ASEAN countries. More specifically, about one-third of the growth in U.S. multinational activity is due to growth in the number of affiliates, while the remaining two-thirds is due to growth in the levels of activity at the affiliate level. Some interesting changes in the direction of U.S. multinational affiliate sales also emerge around the time of the creation of AFTA. In particular, it is possible to distinguish between affiliate sales to their host markets, sales to the U.S., and sales to third countries. In ASEAN countries, sales to third countries increased substantially between 1989 and 1994, while this share remained virtually unchanged in other Asian countries. The growth in the third-country sales share among ASEAN affiliates is driven by both an increase in the share of third-country sales of affiliates that were active before AFTA, as well as the fact that new affiliates in the area direct more of their sales to third countries than other affiliates.

These broad patterns guide the formulation of some theory, which is presented in Section 3. We develop a simple three-country extension of the model of FDI with heterogeneous firms developed in Helpman, Melitz, and Yeaple (2004). The main innovation of our model is the introduction of third-market sales, and our main theoretical results concern the responses of multinational firms based in one country (the West) to a reduction of trade barriers between the other two countries in the model (the South and the East). We interpret this change as regional trade integration between these other two countries. The model predicts an increase in the number of Western firms engaging in FDI in the South-East area. Furthermore, the model indicates the there should be growth on the intensive margin in that affiliates that operate before and after the regional trade agreement should expand. The theory also predicts that regional trade agreements lead to gross entry and exit of Western affiliates operating in the South-East area, with the net effect depending on the distribution of productivity across firms. With a Pareto distribution of productivity, gross entry exceeds gross exit and the extensive margin responds positively to the agreement. The model also has clear implications for the effects 
of the regional trade agreements on the sales of Western affiliates to countries other than their host country. In particular, lowering trade barriers between the East and the South increases the share of affiliate sales going to third countries for three reasons. First, new Western affiliates in the South-East area sell more to third markets than the average Western-owned affiliate does. Second, some Western firms that were active in both South and East before the agreement consolidate activity in one of these countries after the formation of the free trade area and serve the country they leave through regional trade. Finally, affiliates of U.S. parents that are active in only one market (South or East) before and after the regional trade agreement also increase the share of affiliate sales going to third markets.

These predictions are consistent with the broad patterns described in Section 2 of the paper, and Section 4 presents a more rigorous analysis of them. Difference-in-difference estimates illustrate statistically distinctive behavior of U.S. multinational affiliates in ASEAN and other Asian countries. Affiliates that existed in 1989 and 1994 grew faster in ASEAN countries than other countries. Consistent with the theoretical results obtained under a Pareto distribution of productivity, levels of U.S. multinational activity measured at the country/industry level also increase as a result of AFTA. Predictions concerning the direction of affiliate sales also receive support in the data, and there is evidence that the channels by which free trade agreements affect the direction of sales described above are operative. These results hold controlling for other time-varying country specific factors that might confound the results, like differences in GDP per capita growth and changes in tax rates.

These findings contribute to two main literatures. First, they point out a neglected consequence of regional trade agreements: these agreements affect foreign direct investment from countries outside the region. Traditional theoretical analyses of regional trade agreements build on the work of Viner (1950) and focus on the welfare consequences of trade creation and trade diversion effects. Krueger (1999) reviews the theoretical and empirical literature on preferential trade agreements, but this review does not consider effects related to foreign direct investment. Some theoretical work does point out implications for foreign direct investment responses. Motta and Norman (1996), Krugman and Venables (1996), Puga and Venables (1997), and Ekholm, Forslid, and Markusen (2007) each provide a basis by which a reduction in tariffs between two countries would increase foreign investment from third countries. Although relatively few papers empirically test for effects of regional trade agreements on foreign direct investment from outside the region, Chen (2008) is an exception. The results in Chen (2008) indicate marginally significant 
effects of free trade agreements that do not cover the U.S. on aggregate levels of U.S. multinational affiliate sales. Although our theory generates subtle predictions regarding aggregate levels of affiliate sales, our results confirm and expand on those in Chen (2008).

The effects of regional trade agreements on foreign direct investment are likely to have significant welfare consequences given the unique nature of multinational firms. Several strands of the literature indicate benefits for host countries. Aitken, Hanson, and Harrison (1996) and Heyman, Sjöholm, and Tingvall (2007) find that multinational firms pay their workers a premium relative to comparable domestic firms, and Aitken and Harrison (1999) and Smarzynska (2004) show these firms are also more productive than comparable domestic firms. A large body of work, including recent papers by Smarzynska (2004) and Haskel, Pereira, and Slaughter (2007), also points out that multinationals can generate spillovers for other firms through a variety of channels. Depending on the nature of the relation between the foreign and domestic activity of multinationals, the formation of regional trade agreements could also have consequences for the home countries of multinationals that increase their regional investment. Desai, Foley, and Hines (2008) find that domestic and foreign activities are complements, suggesting that increased foreign activity in response to a regional trade agreement could yield some benefits to countries that are the source of foreign direct investment.

Our paper also informs the literature that introduces firm heterogeneity to models of trade and multinational activity. Theoretical attempts at understanding the existence and behavior of multinationals have emphasized horizontal, vertical, and export-platform motivations. ${ }^{1}$ Only recently have researchers attempted to incorporate firm level heterogeneity in these type of models. Helpman, Melitz and Yeaple (2004), Antràs and Helpman (2004), Nocke and Yeaple (2008), and Yeaple (2008a and 2008b) are notable examples of work in this vain. Our model introduces the possibility of export-platform behavior into a model that is similar to the one in Helpman, Melitz, and Yeaple (2004). It then confronts this theory with detailed firm-level data by analyzing how multinationals respond to a specific change in trade costs. By using a detailed panel data set, we are able to explore firm-level responses at both the intensive and extensive margins.

A couple of limitations of our study are worth pointing out. Our empirical tests focus on the formation of a single free trade agreement, and the response to this reform may not

\footnotetext{
${ }^{1}$ The horizontal FDI view represents FDI as the replication of capacity in multiple locations in response to factors such as trade costs, as in Markusen (1984), Brainard (1997), and Markusen and Venables (2000). The vertical FDI view represents FDI as the geographic distribution of production globally in response to the opportunities afforded by different markets, as in Helpman (1984) and Yeaple (2003). Caves (1996) and Markusen (2002) provide particularly useful overviews of this literature.
} 
be representative. Furthermore, given the limited number of countries that signed this agreement and the limited variation in characteristics across them, we have not explored empirically any asymmetries in the effects on foreign direct investment across countries. Our theory could be used to generate further predictions related to country characteristics, however. We also only examine the response of foreign direct investors based in the U.S. While this is largely a consequence of data limitations, it is worth pointing out that the U.S. was by no means a small investor in the area during the period under study. Although it is difficult to find comparable data on measures of foreign investment across host and source countries, the OECD International Direct Investment Statistics database provides information on the outward FDI position of many OECD countries in ASEAN countries. The coverage in this database is reasonably complete, but data are missing for a number of countries that were OECD members during the 1989-1994 period including Belgium, Greece, Iceland, Ireland, Luxembourg, Mexico, Spain, Sweden, and Turkey. Among those countries reporting investment in the ASEAN region, the U.S. held a $22-27 \%$ share of aggregated investment position over the 1989-1994 period. Only Japan (with a share of roughly $50 \%$ ) featured higher levels of FDI in the ASEAN area during that time period.

\section{A First Look at the Data}

In this section, we provide a broad description of U.S. multinational activity in ASEAN countries around the time that AFTA was formed. Aggregate data reveal if levels of U.S. multinational activity increased in ASEAN countries relative to other Asian countries when AFTA was created and if the nature of multinational activity appears to have changed as the costs of serving regional customers fell. In this section, we document some broad empirical trends that help guide the development of the theory and that we later test in a more rigorous manner.

Data on multinationals are drawn from the Bureau of Economic Analysis (BEA) benchmark surveys of U.S. Direct Investment Abroad. In our main analyses, we use data on nonbank affiliates and their parents from the 1989 and 1994 surveys as these years span the formation of AFTA and avoid the 1997 Asian financial crisis. ${ }^{2}$ These data provide a panel of data on the financial and operating characteristics of U.S. multinational firms operating abroad. U.S. direct investment abroad is defined as the direct or indirect owner-

\footnotetext{
${ }^{2}$ Our sample includes nonbank affiliates that filed long or short survey forms; it excludes estimates for affiliates that did not file a survey report. Our sample therefore differs from the data used to produce aggregates published by BEA. Only majoity-owned nonbank affiliates report data used in the analysis presented in Tables 4, 8 and 9 so smaller samples are used in creating these.
} 
ship or control by a single U.S. legal entity of at least ten percent of the voting securities of an incorporated foreign business enterprise or the equivalent interest in an unincorporated foreign business enterprise. A U.S. multinational entity is the combination of a single U.S. legal entity that has made the direct investment, called the U.S. parent, and at least one foreign business enterprise, called the foreign affiliate. As a result of confidentiality assurances and penalties for noncompliance, BEA believes that coverage is close to complete and levels of accuracy are high.

The survey forms that U.S. multinational enterprises are required to complete track basic information on affiliate sales, assets, employment compensation, and net property plant and equipment. In addition, for majority-owned affiliates, the survey forms also capture the direction of sales. More specifically, the survey results provide information on the level of affiliate sales to persons in the affiliate's host country, to persons in the U.S., and to persons in third countries.

Table 1 presents measures of aggregate activity in ASEAN countries and in other Asian countries for the years 1989 and 1994. ${ }^{3}$ The formation of AFTA in 1992 appears to have induced a surge in U.S. MNE activity in the ASEAN countries relative to the rest of Asia, and this surge appears to be a consequence of growth on the intensive and extensive margins. In between 1989 and 1994, the number of affiliates in ASEAN countries increased from 740 to 1,065 or by a margin of $44 \%$. This is larger than the $26 \%$ increase in the number of affiliates in other Asian countries. In addition to high growth in the number of affiliates in the ASEAN region, there is also a sizeable increase in the number of parent firms. In 1989, there were 309 parent firms with operations in ASEAN countries, and by 1994 this number had grown to 403. This rate of growth exceeded the growth in the number of parent firms that were active in other Asian countries. Therefore, a part of the large relative U.S. MNE activity growth in ASEAN countries comes from growth on the extensive margin.

Measures of firm size and factor use increase by larger amounts than affiliate counts. In the ASEAN region, levels of affiliate sales, assets, employment compensation, and net PPE all increase by $125 \%$ or more in between 1989 and 1994, but they increase by only $32-54 \%$ in other Asian countries. These patterns illustrate that growth on the intensive margin is also important in explaining the increase in U.S. MNE activity. In particular, the figures in Table 1 indicate that about two-thirds of the growth in affiliate sales is accounted for by increases in average sales per affiliate (intensive margin) while the remaining one-third

\footnotetext{
${ }^{3}$ The other Asian countries include all non-ASEAN countries in the Asia and Pacific grouping used by BEA.
} 
is explained by growth in the number of affiliates (extensive margin).

Tables 2 and 3 respectively present additional analysis of the intensive and extensive margins of growth. Table 2 presents similar information to that in Table 1, but it only aggregates measures of activity for affiliates that exist in 1989 and survive until 1994. For this group of affiliates, aggregate levels of sales, assets, employment compensation, and net PPE more than double in ASEAN countries, but increase by much lower amounts in other Asian countries.

Table 3 displays aggregate measures of activity for affiliates that exit and enter the data. The first column shows 1989 measures for affiliates that exist in the 1989 data but that leave the sample before 1994. The second column shows 1994 measures for affiliates that report in 1994 but that did not exist in the data in 1989. Comparing the first and second columns therefore provides insights about the effects of net entry on the extent of U.S. MNE activity. As suggested by the aggregate data, net entry is much larger in ASEAN as opposed to other Asian countries. In ASEAN countries, the count of 558 new affiliates in 1994 is about 2.4 times the count of 233 affiliates which exit the data. In other Asian countries, however, the ratio of entering affiliates to exiting affiliates is only about 1.8. Aggregate measures of sales, assets, employment compensation, and net PPE are approximately 3 times larger for entering than exiting affiliates in ASEAN countries. In other Asian countries, these measures are similar for entering and exiting affiliates. Thus, the large increase in U.S. MNE activity in ASEAN countries around the time of the signing of AFTA, reflects an increase in the size of affiliates that existed in 1989 and survive until 1994 as well as higher levels of entry relative to exit in ASEAN countries.

For majority-owned affiliates, the BEA data also include information on sales by destination, including sales to persons in the affiliate's host country, sales to persons in the U.S., and sales to persons in third countries. Sales to third countries would include sales by affiliates to persons in ASEAN countries other than the affiliate's host country, and the theory developed in the next section indicates that these kinds of sales should increase around the formation of AFTA. Table 4 presents descriptive statistics on sales shares that are computed using aggregate data. For the top panel, data on all affiliates are used to compute sales shares for different types of sales for firms in ASEAN and other Asian countries. $^{4}$ Compared to affiliates in other Asian countries, affiliates in ASEAN countries direct a smaller fraction of their sales to their host market and larger fractions to the U.S. and to third countries.

\footnotetext{
${ }^{4}$ In order to avoid the possible disclosure of confidential information, published aggregate data that exclude Brunei are used to compute the figures in the top panel.
} 
Examining changes in sales patterns suggests that AFTA did indeed increase the share of sales to third countries for affiliates in the ASEAN region relative to affiliates in the rest of Asia. The share of sales to third countries for affiliates in ASEAN countries increased from $28.3 \%$ to $32.5 \%$ between 1989 and 1994 while this share decreased slightly in other Asian countries, equaling $12.8 \%$ in 1989 and $11.2 \%$ in 1994 . Accompanying these changes, the share of sales to persons in the affiliate's host country increased by slightly higher amounts in other Asian countries. The share of sales to the U.S. fell for affiliates in both sets of countries and by larger amounts in ASEAN as opposed to other Asian countries.

Panels B and $\mathrm{C}$ of Table 4 provide information on the direction of sales for affiliates that exist in 1989 and 1994 as well as for affiliates that enter and exit. Panel B displays data for the survivors, and it reveals patterns that are very similar to those observed for the whole sample. The share of sales to third countries disproportionately increases for affiliates in ASEAN countries. In Panel C, the first column displays 1989 sales shares for affiliates that appear in 1989 but exit before 1994, and the second column displays 1994 sales shares for affiliates that do not appear in 1989 but enter in 1994. In ASEAN countries, new entrants are more focused on selling to third countries and less focused on selling to the host market and the U.S. than exiting affiliates. $41.2 \%$ of the 1994 sales of new entrants is directed to third countries, but only $33.3 \%$ of exiting affiliate 1989 sales is directed to these markets. However, an opposite pattern appears for entrants and exits in other Asian countries. In these countries, 10.1\% of the 1994 sales of new entrants is directed to third markets, and this share is $16.0 \%$ for the affiliates that exited. Therefore, growth in the share of sales to third countries among affiliates in the ASEAN region in part reflects growth in this share for surviving affiliates and in part reflects growth that is a consequence of new affiliates having relatively high shares of third-country sales.

Further unreported analysis suggests that models of horizontal foreign direct investment are more salient in explaining the response of U.S. multinationals than models of vertical foreign direct investment. If multinationals increased their vertical specialization within regions that entered into a trade agreement, one should observe firms expand into several regional countries and increase their level of sales by affiliates in one part of the region to affiliates in other parts of the region. While U.S. multinational firms do appear to expand within the ASEAN region, those firms that increase the number of countries in which they operate do not appear to have high or increasing levels of intrafirm regional transactions.

In summary, aggregated descriptive statistics indicate that U.S. multinational activity 
in the ASEAN region disproportionately increased at the time of the formation of AFTA. This increase reflects growth on the intensive and extensive margins. Within the ASEAN region, the share of affiliate sales to countries other than host countries also increases, and it appears that the increase is a consequence of changes among affiliates that operate before AFTA as well as changes in the composition of activity because of net entry. These aggregate patterns do not, however, indicate the statistical significance of differences in firm behavior. Furthermore, because aggregate measures are particularly sensitive to the activities of large firms, the patterns in the aggregates might not indicate the experiences of the typical firm. Aggregate patterns could also reflect other trends in ASEAN and other Asian countries, like difference in per capita growth rates or changes in tax policy. In order to address these considerations, it is helpful to employ the firm-level data in more rigorous regression analysis. However, before doing so we develop some theory that serves as a guide to the analysis.

\section{Theoretical Framework}

In this section, we develop a simple model to illustrate the effects of a regional trade agreement on the patterns of FDI in the set of countries signing the agreement. Our goal in developing the model is to provide a simple rationale for the broad empirical patterns described in the previous section and to formally develop a set of hypotheses that are explored econometrically in the next section.

\subsection{A Simple Model of FDI}

Our model is a simple variant of the framework in Helpman, Melitz and Yeaple (2004). ${ }^{5}$ We consider a world of three countries: the West, the East and the South. The model studies the optimal international organization of production from the point of view of firms based in the West, which in the empirical analysis we associate with the United States. These firms own the technology to produce a differentiated good with demand

$$
y=A^{j} p^{-\sigma}
$$

in country $j=W, E, S$. There is a continuum of firms based in the West, which we index by their heterogeneous productivity level $\varphi$, and we let the cumulative distribution

\footnotetext{
${ }^{5}$ Similar extensions are developed by Yeaple (2003, 2008a and 2008b) and Grossman, Helpman and Szeidl (2006), but the focus of those papers is very different.
} 
function of productivity be $G(\varphi)$.

Final goods are produced combining skilled and unskilled labor. We allow firms to produce their final good in each of the three countries, which we index by $\varrho=W, E, S$. The unit variable cost of production for a firm with productivity $\varphi$ producing in country $\varrho$ is given by

$$
c^{\varrho}(\varphi)=\frac{1}{\varphi}\left(w_{S}^{\varrho}\right)^{\beta}\left(w_{U}^{\varrho}\right)^{1-\beta},
$$

where $w_{S}^{\varrho}$ denotes the wage rate of skilled workers in the country where the good is produced, and $w_{U}^{\varrho}$ denotes the analogous wage rate for unskilled workers.

Although our main results go through when all countries have the same factor prices, we shall assume that the unskilled-labor wage is lower in the South than in the East or West, i.e.,

$$
w_{U}^{W}=w_{U}^{E}>w_{U}^{S}
$$

For simplicity, we assume that the wage of skilled workers is identical in all three countries and we set it equal to one (so skilled labor is the numeraire in the model), i.e.,

$$
w_{S}^{W}=w_{S}^{E}=w_{S}^{S}=1
$$

It is straightforward to develop a general equilibrium version of the model that produced these factor prices as equilibrium prices. In terms of of our empirical application, one can think of the East as being a relatively skilled-labor abundant Southeast Asian country (such as Singapore) and the South as being a relatively unskilled-labor abundant Southeast Asian country (such as the Philippines). ${ }^{6}$

Production entails a fixed cost $f^{\varrho}$ in terms of skilled labor (the numeraire) and the size of this fixed cost depends on the location of production. In particular, we assume that firms in the West need to incur a higher fixed cost when operating in East or South than when operating in their home country (i.e., the West), consistent with the assumptions in Helpman, Melitz and Yeaple (2004). For simplicity, we set the fixed cost of production in the West equal to 0 , and we let $f^{E}=f^{S}=f>0$.

Final goods are tradable, but at a variable cost equal to $\bar{\tau}$ between the West and each of the two other countries and equal to $\underline{\tau}<\bar{\tau}$ between the East and South. We shall interpret a regional trade agreement between East and South as a drop in $\underline{\tau}$ while holding

\footnotetext{
${ }^{6}$ As explained in the Introduction, our empirical analysis does not study these country asymmetries. We, however, found it natural to develop a theoretical framework that can be used for future empirical investigations.
} 
$\bar{\tau}$ constant. $^{7}$ For reasons that will become apparent below, we shall also assume that the following inequality holds (though we discuss what happens when this assumption is relaxed):

Assumption 1: $\underline{\tau}>\left(w_{U}^{E} / w_{U}^{S}\right)^{(1-\beta)}$.

We next compute the profits associated with the different organizational strategies of a firm in the West with productivity $\varphi$. A first convenient implication of Assumption 1 is that it ensures that the Western market is necessarily served domestically, that is from a plant located in the West. ${ }^{8}$ Hence, the key organizational decision in the model is whether to also have a plant in East and/or the South. Because the profits obtained from sales in the West are independent of this organizational decision, we ignore them hereafter.

Consider first the case in which the firm in the West only has one plant and this plant is located in the West. In such a case, the East and the South are serviced through exports from the West. Given the demand levels in East and South and the unit variable cost of production $c^{\varrho}(\varphi)=\left(w_{U}^{W}\right)^{1-\beta} / \varphi$, it is straightforward to compute the join profits associated with this strategy:

$$
\pi^{X}(\varphi)=\frac{1}{\sigma}\left(\frac{(\sigma-1) \varphi}{\sigma}\right)^{\sigma-1} \frac{\bar{\tau}^{1-\sigma}\left(A^{E}+A^{S}\right)}{\left(w_{U}^{W}\right)^{(1-\beta)(\sigma-1)}} .
$$

Alternatively, the firm in the West could decide to open one plant in the East. This option would not affect the variable unit cost of production $\left(w_{U}^{W}=w_{U}^{E}\right)$ and would increase fixed costs by an amount $f$, but it would also reduce shipping costs associated with servicing the East and the South. ${ }^{9}$ The profits in East and South associated with this option are:

$$
\pi^{I-E}(\varphi)=\frac{1}{\sigma}\left(\frac{(\sigma-1) \varphi}{\sigma}\right)^{\sigma-1}\left(\frac{A^{E}+\underline{\tau}^{1-\sigma} A^{S}}{\left(w_{U}^{E}\right)^{(1-\beta)(\sigma-1)}}\right)-f .
$$

Similarly, the firm in the West could decide to set up one plant in the South, an option

\footnotetext{
${ }^{7}$ Althought a free trade area would drive trade policy costs to zero, natural trade barriers would still imply $\tau>1$.

${ }^{8}$ It is clear that as long as $w_{U}^{W}=w_{U}^{E}$, a firm would never want to service the West with exports from a plant located in the East because this would entail positive transport costs and a higher fixed cost. Provided that $w_{U}^{S}$ or $\bar{\tau}$ is sufficiently high (as Assumption 1 imposes), servicing the West from a plant in the South is not optimal either.

${ }^{9}$ Because $\bar{\tau}>\underline{\tau}$, the firm would choose to service the South via exports from the plant in the East. Hence, under this strategy, exports from the West are equal to 0.
} 
that would generate joint profits in East and South equal to

$$
\pi^{I-S}(\varphi)=\frac{1}{\sigma}\left(\frac{(\sigma-1) \varphi}{\sigma}\right)^{\sigma-1}\left(\frac{\underline{\tau}^{1-\sigma} A^{E}+A^{S}}{\left(w_{U}^{S}\right)^{(1-\beta)(\sigma-1)}}\right)-f .
$$

The final alternative available to firms in the West is to set up production plants in both East and South, in which case each of the three markets is serviced through local sales. Straightforward calculations deliver a joint profit level in East and South equal to

$$
\pi^{I-E S}(\varphi)=\frac{1}{\sigma}\left(\frac{(\sigma-1) \varphi}{\sigma}\right)^{\sigma-1}\left(\frac{A^{E}}{\left(w_{U}^{E}\right)^{(1-\beta)(\sigma-1)}}+\frac{A^{S}}{\left(w_{U}^{S}\right)^{(1-\beta)(\sigma-1)}}\right)-2 f .
$$

\subsection{Analysis}

Having computed the profits associated with each of these options, we next analyze how the optimal organizational form of firms varies with levels of productivity $\varphi$. In particular, we will identify the organizational mode $k \in\left\{X, I_{-} E, I_{-} S, I_{-} E S\right\}$ that maximizes profits $\pi^{k}(\varphi)$. For that purpose, it proves convenient to follow Helpman, Melitz and Yeaple (2004) and Antràs and Helpman (2004) in expressing the profit function associated with each alternative as a linear function of the modified productivity measure $\varphi^{\sigma-1}$, that is

$$
\pi^{k}(\varphi)=\psi^{k} \varphi^{\sigma-1}-f^{k}
$$

where $f^{k}$ is the fixed cost associated with option $k$ and where $\psi^{k}$ can be backed out from equations (1) through (4).

Our first observation is that because the fixed cost associated with the strategies $I_{-} E$ and $I_{-} S$ is identical, the choice between these two options depends only on the relative magnitude of $\psi^{I-E}$ and $\psi^{I-S}$ and is thus independent of productivity. Manipulation of equations (2) and (3) indicates that investing only in the East dominates investing only in the South whenever

$$
\frac{A^{E}+\underline{\tau}^{1-\sigma} A^{S}}{\underline{\tau}^{1-\sigma} A^{E}+A^{S}}>\left(\frac{w_{U}^{E}}{w_{U}^{S}}\right)^{(1-\beta)(\sigma-1)} .
$$

Other things equal, investment in the East is more likely to be chosen if the market size of the East is large relative to the South (if $A^{E}$ is large relative to $A^{S}$ ) and if the cost of production in the East is not disproportionately high relative to the South, which is true when wage differences are small (i.e., when $w_{U}^{E} / w_{U}^{S}$ is low) or when production is relatively skill-intensive (when $\beta$ is high). Finally, a high shipping cost between East and 
South (a high $\underline{\tau}$ ) also favors FDI in East provided that $A^{E}>A^{S}$, while it favors FDI in South whenever $A^{S}>A^{E}$. Intuitively, when there is only one plant in the Southeast area, higher transportation costs between South and East generate an incentive to concentrate production in the relatively large country. By the same argument, a fall in $\underline{\tau}$ reduces the importance of market size in determining the location of MNE activity and increases the role of factor cost considerations.

We next compare the option of exporting from the West with the three alternative FDI strategies. Combining equation (5) with equations (1)-(4) and using Assumption 1, it is simple to establish that the following inequalities hold:

$$
\psi^{I-E S}>\max \left\{\psi^{I_{-} E}, \psi^{I_{-} S}\right\}>\min \left\{\psi^{I_{-}}{ }^{E}, \psi^{I-S}\right\}>\psi^{X},
$$

and

$$
f^{I_{-} E S}=2 f>f^{I_{-}}{ }^{E}=f^{I_{-} S}=f>f^{X}=0 .
$$

These rankings immediately imply that a sufficiently productive Western firm chooses some form of FDI over exporting, while a firm with a sufficiently low productivity level necessarily prefers exporting to any form of FDI. ${ }^{10}$ These results parallel those obtained by Helpman, Melitz and Yeaple (2004), but our analysis permits a comparison of singleplant FDI with multiple-plant FDI and allows for the possibility of affiliate exports. The rankings above immediately imply that only the most productive firms find it profitable to establish affiliates in both the East and the South, while firms with intermediate levels of productivity may decide to undertake FDI in just one of the two countries. ${ }^{11}$

We use Figure 1 to illustrate these results. As in Helpman, Melitz and Yeaple (2004) and Antràs and Helpman (2004), we plot the profit functions of all four possible organizational modes as a function of the modified productivity measure $\varphi^{\sigma-1}$. As is clear from the Figure, firms with low productivity $\varphi\left(\varphi<\varphi_{X}^{*}\right)$ find it optimal to service both East and South via exporting. Conversely, firms above a certain productivity threshold $\left(\varphi>\varphi_{I E S}^{*}\right)$ optimally choose to set up plants in both countries. Finally, firms with intermediate productivity levels, this is $\varphi \in\left(\varphi_{X}^{*}, \varphi_{I_{-} E S}^{*}\right)$, have one plant in either East or South and will not export from the West. The location of this plant depends on whether

\footnotetext{
${ }^{10}$ In particular, note that $\pi^{I_{-}} E(\varphi)-\pi^{X}(\varphi), \pi^{I_{-}} S(\varphi)-\pi^{X}(\varphi)$ and $\pi^{I_{-}} E S(\varphi)-\pi^{X}(\varphi)$ all increase unboundedly with $\varphi$. Furthermore, as $\varphi \rightarrow 0$, only the exporting option remains profitable.

${ }^{11}$ When Assumption 1 does not hold, the operating profits associated with setting up only one affiliate in the South are strictly higher than those obtained when setting up only one affiliate in the East and when setting up an affiliate in both the East and the South. In such a case, the least productive firms export, while the most productive firms engage in single-plant FDI in the South. No other organizational mode is optimal in equilibrium.
} 


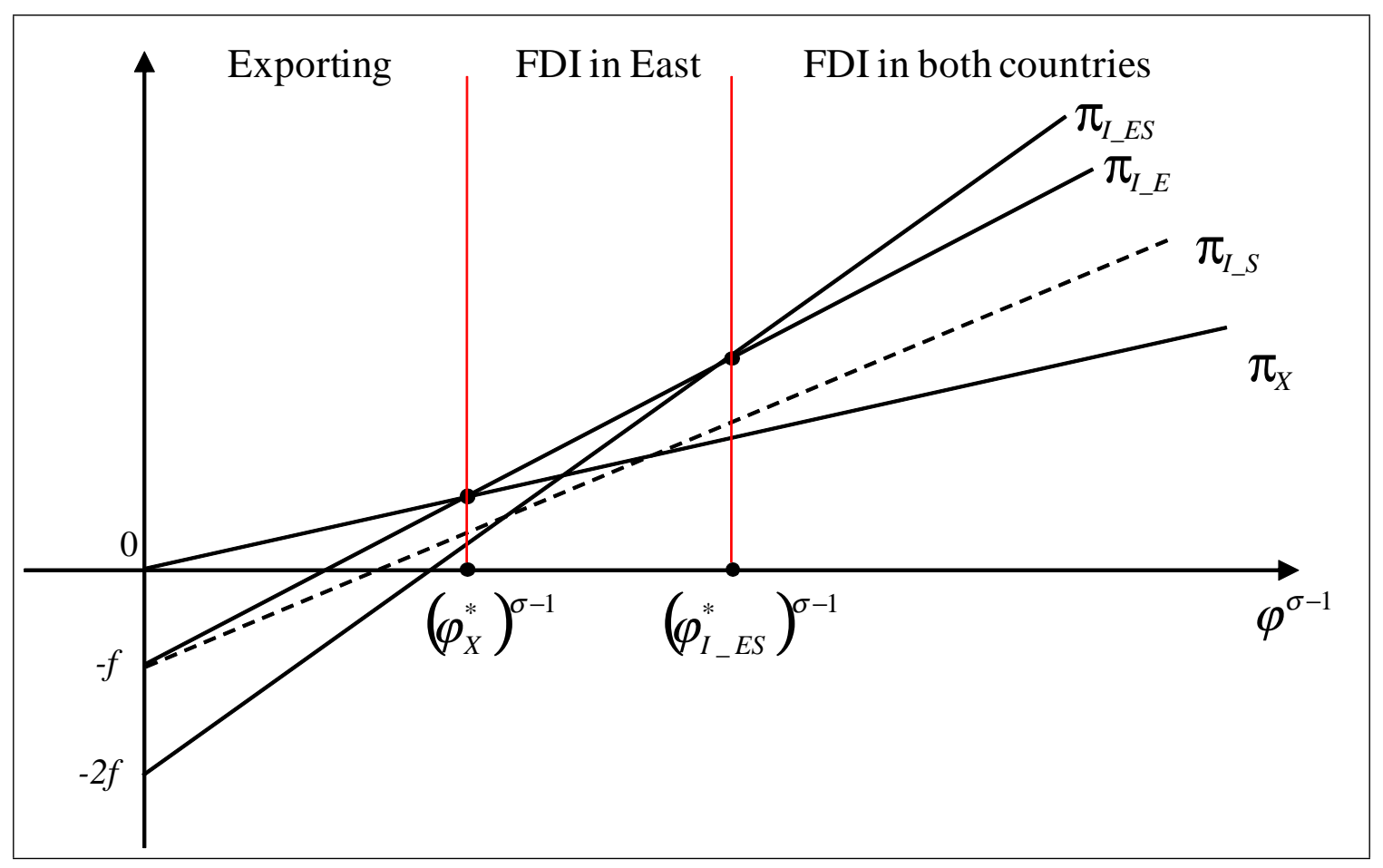

Figure 1: Sorting of Firms into Organizational Modes

condition (6) holds. Figure 1 illustrates the case in which condition (6) holds (perhaps because the Eastern market size is larger or because the good is relatively skill-intensive) and the plant is located in the East.

\subsection{Effects of a Regional Trade Agreement}

We can now consider the effects of a regional trade agreement between the East and the South, which we associate with a fall in $\underline{\tau}$ in the model, holding other parameters constant. ${ }^{12}$ Notice that the profits associated with the exporting decision and the multipleplant FDI decision are independent of $\underline{\tau}$, while the profitability of each of the two FDI strategies involving one plant is positively affected by the fall in $\underline{\tau}$. Although the free trade area does not increase the sales and profits in the market where the affiliate is located, it does increase the attractiveness of this plant as an export-platform to the other country in the FTA. In terms of Figure 1, the slopes of the functions $\pi^{I-}{ }^{E}$ and $\pi^{I}{ }^{S} S$ necessarily increase, which translates into a fall in the threshold $\varphi_{X}^{*}$ and entry of new

\footnotetext{
${ }^{12}$ In reality, an FTA would be likely to affect other variables in the model, such as wage rates and the demand level. We attempt to control for these factors in the econometric exercises in Section 4.
} 
Western affiliates in the South-East area. This in turn implies that, consistent with the findings reported in Table 1:

Prediction 1 An FTA between the East and the South increases the number of Western firms engaging in FDI in the South-East area.

A second implication of the increase in the slopes of the profit functions $\pi^{I-E}$ and $\pi^{I-S}$ is that the threshold $\varphi_{I_{-} E S}^{*}$ necessarily goes up as a result of the regional trade agreement. Consequently, some Western firms that initially had two affiliates in the South-East area now optimally choose to shut down one of their plants and concentrate the location of production in only one country in the area. The model thus predicts gross entry and exit as a result of the FTA, and the net effect on the number of Western affiliates located in the South-East area is in general ambiguous. However, when the distribution of productivity across firms is Pareto distributed (an assumption consistent with available evidence), it is possible to show that gross entry of affiliates exceeds gross exit. Under this assumption, the model predicts an increase in the number of Western affiliates operating in the SouthEast area (see the Appendix for details). Consistent with the findings described in Section 2, we have that:

Prediction 2 An FTA between East and South generates gross entry and gross exit of Western affiliates in the South-East area. Furthermore, when firm productivity follows a Pareto distribution, the FTA generates a net increase in the number of Western affiliates in the South-East area.

We next consider the effects of the regional trade agreement on measures of affiliate activity. Although in Section 2, we document changes in four alternative measures of activity, we focus for the most part on deriving predictions for affiliate sales, which is the measure most easily retrievable from the model. It is simplest to first discuss predictions at the affiliate level. In our model, because firm-level sales are proportional to firm-level operating profits, it follows from our discussion above that affiliates that exist before the regional trade agreement (weakly) increase their level of sales as a result of the fall in South-East trade barriers. This increase is qualified with the word weakly because firms with two affiliates before and after the FTA are not predicted to change their activity as a result of the FTA. Noting that factor prices are independent of $\underline{\tau}$ and that the variable cost function is homothetic, we can also conclude that other measures of affiliate activity, such as assets, employment compensation, and net property plant and equipment (net PPE) also (weakly) increase as a result of the FTA. Hence, we can state that: 
Prediction 3 Conditional on survival, an FTA between the East and the South weakly increases economic activity (in terms of sales, assets, employment compensation, and net PPE) at the affiliate level.

This prediction is consistent with the intensive margin results in Table 2, but the prediction is more nuanced in that we predict growth at the affiliate level, rather than just an increase in affiliate sales among surviving affiliates. We test this prediction in the next section.

Does Prediction 3 necessarily imply that aggregate affiliate sales in the South-East area increases as a result of the FTA, as we documented in Section 2? Not necessarily. As shown above, the FTA leads to gross exit of some plants in the area, as some two-plant MNEs become one-plant MNEs. Affiliate sales for this group of MNEs necessarily falls as a result of the FTA, and this decrease may not be offset by the increase in sales of surviving affiliates. The overall effect on aggregate affiliate sales depends of the distribution of productivity in the population, just as our prediction on the number of affiliates does. We show in the Appendix that when productivity follows a Pareto distribution, aggregate affiliate sales are indeed decreasing in $\underline{\tau}$. In sum, we have that:

Prediction 4 When firm productivity follows a Pareto distribution, the FTA leads to an increase in aggregate affiliate sales in the South-East area.

We can derive further predictions by studying the direction of sales implied by the model. Notice that Western firms with affiliates in both the East and the South will have affiliates that sell all of their output in their local market. Hence, the level of affiliate third-country sales is zero both for exporters as well as for two-plant MNEs. On the other hand, under condition 6 , firms with productivity $\varphi \in\left(\varphi_{X}^{*}, \varphi_{I_{-} E S}^{*}\right)$ sell an amount

$$
\left(\frac{(\sigma-1) \varphi}{\sigma}\right)^{\sigma-1} \frac{A^{E}}{\left(w_{U}^{E}\right)^{(1-\beta)(\sigma-1)}}
$$

in the Eastern (local market) and an amount

$$
\left(\frac{(\sigma-1) \varphi}{\sigma}\right)^{\sigma-1} \frac{\underline{\tau}^{1-\sigma} A^{S}}{\left(w_{U}^{E}\right)^{(1-\beta)(\sigma-1)}}
$$

in the Southern market. The ratio of affiliate third-market sales to local sales is thus given by $\underline{\tau}^{1-\sigma} A^{S} / A^{E}$. It is independent of productivity and decreasing in $\underline{\tau}$. When condition (6) does not hold, single-affiliate firms operate in the South, but the share of third-country 
sales by affiliates is either 0 or a positive number that decreases in $\underline{\tau}$. Putting all the pieces together, we can conclude that:

Prediction 5 An FTA between the East and the South increases the share of affiliate sales going to third countries for three reasons. First, new entrants into the SouthEast area sell more to third markets than the average Western-owned plant in the area. Second, firms that consolidate two affiliates into one have affiliates with positive sales to third markets, and they did not before. Third, firms with only one affiliate before and after the FTA also increase the share of affiliate sales going to third markets.

In Table 4 we presented broad patterns consistent with these predictions, but we test these predictions more formally in the next section.

\section{Econometric Evidence}

The first prediction from the theory is that the formation of the free trade area increases the number of U.S. MNEs operating there. The number counts in Table 1 suggest this is the case. There is also evidence for Prediction 2 in that the number of affiliates in the ASEAN region increases, and the rate of increase exceeds the rate of increase in other Asian countries. In order to consider the evidence for the other predictions, we turn to detailed firm level data. Table 5 provides descriptive statistics for these data.

Prediction 3 of the theory holds that affiliates that exist before the formation of the FTA and survive should increase their activity. The specifications presented in Table 6 test for this effect. The tests explain growth in measures of U.S. MNE activity over the 1989-1994 period using measures of changes at the affiliate level. Therefore, the data only measure growth on the intensive margin because changes can only be measured for affiliates that are observed in both 1989 and 1994. The sample includes observations from all ASEAN countries as well as other Asian countries. The main coefficient of interest is the one on the ASEAN dummy; it reveals if affiliate growth within the ASEAN region is larger than growth elsewhere in Asia. The specifications also control for per capita GDP growth and changes in the corporate tax rate. Heteroskedasticity consistent standard errors that allow for clustering at the country level are computed and appear in parentheses.

The dependent variable in the first two columns is sales growth, and it is measured by taking the difference between end and beginning of period values of sales and dividing 
by average values. The 0.1638 coefficient on the ASEAN dummy in column 1 is positive and significant, as is the coefficient on this variable in column 2. The specifications in columns 3-8 explain asset growth, employment compensation growth, and growth in net $\mathrm{PPE}$, and the coefficient on the ASEAN dummy is positive and significant in each of the specifications except those presented in column 6 and $7 .{ }^{13}$ These results imply that affiliates that were active in the ASEAN region before and after the formation of AFTA increase their activity by larger amounts than surviving affiliates that operate in other Asian countries over a similar period. These findings are consistent with the claim that FTAs have a positive effect on the level of activity of affiliates that existed before the FTA and remain active after its formation.

The theory does not carry decisive predictions concerning how the formation of an FTA affects overall levels of multinational production and sales. Although new firms enter the FTA region and surviving affiliates expand, fixed costs of investment can induce some firms to close an affiliate and serve that affiliate's host country through trade, thereby reducing aggregate sales. Prediction 4 indicates, however, that the latter effect is dominated in the plausible case of a Pareto distribution of productivity. In order to empirically analyze the net impact of these effects, we perform the tests presented in Table 7. These tests are similar to those presented in Table 6 , but the data are aggregated to the country/industry level. Therefore, the estimates of the coefficient on the ASEAN dummy captures growth that is due to the net entry of affiliates in addition to the growth of surviving affiliates. These coefficients are slightly larger in the specifications in Table 7 relative to Table 6, and they are all significant except the one in column 2. The slightly larger estimates on the ASEAN dummy indicate that part of the disproportionately high levels of growth of U.S. MNE activity in ASEAN countries is a consequence of net entry, or the extensive margin. Consolidation of activity by firms following the formation of AFTA is more than offset by the entry of new firms. This result would be predicted under many distributions of productivity, like a Pareto distribution, as indicated in Prediction 4.

Prediction 5 suggests that a part of growth in affiliate sales observed in Table 6 is due to growth in sales to third countries. Specifically, the theory indicates that surviving affiliates of those firms that are active in only one country after the formation of AFTA should increase their sales to third countries. Such firms include firms that were active in more than one country prior to AFTA and consolidated activity as well as firms that

\footnotetext{
${ }^{13}$ Statements about levels of significance are based on the large sample properties of t-statistics. If one assumes that the degrees of freedom is equal to the number of clusters, which is 22 for the number of countries in the data, results presented in column 8 of Table 6 and column 6 of Table 9 are only significant at the $6 \%$ level.
} 
operated in one country both before and after the formation of AFTA.

The specifications presented in Table 8 test for this possibility. The dependent variables are components of sales growth; they are measures of sales growth due to sales to the host country, to the U.S., and to third countries. Each component of sales growth is measured by scaling the first difference in sales to a particular location by the average of beginning and end of period aggregate affiliate sales. Therefore, the three components of sales growth sum to the measure of affiliate sales growth analyzed in columns 1 and 2 of Table 6. The specifications in the odd numbered columns are similar to those in previous tables, but those in the even numbered columns differ in that they include the ASEAN dummy interacted with a dummy that is equal to one for firms that operate in only a single ASEAN country after the formation of AFTA. In these specifications, the coefficient on the ASEAN dummy captures the effects of being in an ASEAN country around the time of the formation of AFTA, and the coefficient on the interaction term identifies if the effects of being in an ASEAN country differ for firms that operate in a single ASEAN country in 1994. We introduce this interaction because our model predicts a growth in third-market sales only for the subset of affiliates owned by U.S. multinational firms with a single affiliate in ASEAN countries after the formation of AFTA.

The -0.0018 coefficient on the ASEAN dummy in column 1 indicates that AFTA did not increase sales to the host country. In the second column, this coefficient remains insignificant, and the coefficient on the interaction term is also insignificant, indicating that AFTA did not differentially affect the local sales of firms operating in one ASEAN country after the formation of AFTA. The next two columns analyze the growth in sales due to U.S. sales. The positive and significant coefficient on the ASEAN dummy in column 3 and the positive and marginally significant coefficient on it in column 4 suggest that sales to the U.S. increased around the time AFTA was created. There does not appear to be any differential effect for firms that compete in only a single ASEAN country after the formation of AFTA. While interesting, this result is beyond the scope of the theory. The final two columns analyze the growth in sales due to third country sales, which the model emphasizes. The 0.0391 coefficient in column 5 is positive but not significant, suggesting that the share of sales to third countries does not increase on average for all affiliates. The positive and significant coefficient on the interaction term in the specification in column 6 is consistent with Prediction 4. AFTA appears to increase the third country sales of affiliates of firms that operate in a single ASEAN country after the FTA, either because they have consolidated or maintained their activities.

Prediction 5 also asserts that the share of sales to third countries should increase in 
response to the formation of an FTA in part because new affiliates sell more to third countries than preexisting affiliates. The tests presented in Table 9 consider this possibility. The specifications explain the share of sales to the host country, to the U.S., and to third countries for the sample of affiliates in Asia in 1994. The specifications include an ASEAN dummy, a dummy for new affiliates, the interaction of these two, and controls for the log of per capita GDP and the corporate tax rate. In these specifications, the coefficients on the ASEAN dummy estimate the difference in sales shares for ASEAN as opposed to other Asian affiliates, the coefficient on the new affiliate dummy picks up differences in sales shares for new affiliates, and the coefficient on the interaction term identifies if new affiliates have distinctive sales patterns relative to preexisting affiliates in ASEAN countries. Prediction 5 suggests the coefficient on this interaction term should be positive in specifications explaining the share of sales to third countries.

The new affiliate dummy is defined in two ways. In the odd numbered columns, this variable is equal to one for all affiliates that appear in the data in 1994 but not in 1989 . In the theory, firms that establish new affiliates in response to the formation of an FTA establish a single affiliate. However, the theory does not consider a variety of factors that might induce a firm to enter many ASEAN markets after the creation of AFTA. For example, firms could face trade costs within the ASEAN region that reflect nontariff costs of moving their goods. Such firms may be induced to enter two or more ASEAN countries following the introduction of AFTA, directing a large fraction of their sales to the host country. In the even numbered columns, the new affiliate dummy is defined to equal one for new affiliates in ASEAN countries provided that the affiliate's firm operates in only a single ASEAN country in 1994. It is also equal to one for all new affiliates in other Asian countries. The interaction term therefore isolates effects for the type of new affiliate that is considered in the theory.

The coefficients on the ASEAN dummies indicate that surviving affiliates in ASEAN countries have a lower share of host country sales and a higher share of U.S. and third country sales than surviving affiliates in other Asian countries. The coefficients on the dummy for new affiliates are all insignificant, implying that new affiliates in other Asian countries do not exhibit a pattern of sales that is distinctive from surviving affiliates in those countries. The coefficients on the interaction terms are also insignificant, except for the one in the last column. The positive and significant 0.0738 coefficient implies that new affiliates in ASEAN countries that are a part of firms that operate in only a single ASEAN country have higher shares of sales to third countries than other affiliates in ASEAN countries. This difference in the direction of sales for new affiliates is not 
observed in the rest of Asia. These results are consistent with Prediction 5.

These empirical results are subject to a number of reasonable concerns, and we have conducted several robustness tests to address these. A couple of issues might distort the findings on affiliate growth presented in Tables 6 and 7. First, the disproportionate growth of affiliate activity in ASEAN countries could reflect low levels of affiliate growth in other Asian countries rather than high levels of affiliate growth in ASEAN countries. Several factors could induce such a pattern. For example, the formation of AFTA may attract U.S. foreign investment away from other regional countries. In order to consider this possibility, we conduct the tests presented in Table 6 and 7 using a sample that is comprised of affiliates in ASEAN countries and affiliates in European countries. The results obtained using this sample are qualitatively similar to the results presented in the paper with the exception that the coefficient on the ASEAN Dummy in the specification presented in column 8 of Table 6 is no longer significant. ${ }^{14}$ The results in each table are also largely robust to removing Australia and Japan from the sample of other Asian countries; these nations are large and developed, and multinational activity in them may be distinctive.

Second, many of the provisions of the ASEAN FTA did not take effect until after 1994, so it is potentially informative to study growth in activity over the 1989 to 1999 period as opposed to the 1989 to 1994 period. We have conducted the tests presented in Table 6 and 7 of the paper using this longer sample period. The coefficients on the ASEAN dummy in these specifications generally maintain their significance, but these coefficients are insignificant in the specifications presented in columns 5 and 6 of Table 6 , and the coefficient on the ASEAN dummy in the specification presented in column 6 of Table 7 is only marginally significant.

The specifications presented include a parsimonious set of controls. Other country characteristics could be changing at the same time that AFTA is formed, and these might confound our results on patterns in affiliate growth. For example, the extent to which countries place restrictions on foreign direct investment or changes in political regimes could be coincident with the formation of AFTA and explain patterns in U.S. multinational growth. To address this issue, we have conducted the analysis in Tables 6 and 7 including controls for changes in FDI restrictions drawn from Shatz (2000) and for political regime changes drawn from Marshall and Jaggers (2009). ${ }^{15}$ Some results are

\footnotetext{
${ }^{14}$ Although it is less clear why these considerations would bias the results in Tables 8 and 9 , we have also checked the robustness of our results in those tables, and the results are similar.

${ }^{15}$ Changes in FDI restrictions are measured as changes in a dummy that is set equal to one if the acquisition or sector scores in Shatz (2000) are less than 3. Regime changes are measured as changes in
} 
only marginally significant when these controls are included, but for the most part the results are little changed by them. We do not include these controls in the specifications we present because these data cover only a subset of the countries in the BEA data.

Although the BEA data include firms in all industries, the theory envisions a firm that uses labor to produce a tradeable good. Therefore, the predictions might be more relevant to manufacturing firms than they are to firms in other industries. We have performed the analysis in Tables 6-8 limiting the sample to affiliates in manufacturing industries. The results of the tests in Table 6 and 7 are stronger than those obtained using the full sample, but the tests presented in columns 6 of Table 8 and 9 are no longer significant, perhaps because the sample size is smaller.

Finally, we have rerun all of the specifications dropping each ASEAN country, one at a time, to see if activity related to a particular country drives the results. Although this yields some variation in the estimates, no single ASEAN country is central to the results.

\section{Conclusion}

Even though existing studies of regional trade agreements focus on their impact on trade flows, these agreements appear to have large effects on the level and nature of multinational firm activity. In this paper we build on recent theoretical work to develop a model of the behavior of heterogenous firms based in one country when there is a reduction in the tariffs on trade between two other countries. This model generates a series of predictions that we consider in the context of how U.S. multinational firms responded to the formation of the ASEAN free trade agreement. Examination of aggregate data and more detailed firm-level analysis indicates that measures of U.S. multinational activity increase at the time AFTA is created. Specifically, the number of U.S. firms that are active in the region increases at a faster rate than the number of U.S. firms active in other Asian countries. Affiliates within the ASEAN regions grow by larger amounts than affiliates elsewhere. There are also distinct shifts in the direction of sales of ASEAN affiliates. These affiliates increase the share of sales to countries other than the U.S. and the affiliate's host country. This increase reflects two channels for firms that focus their activity in a single ASEAN country after the formation of AFTA. First, there are high levels of growth in third-country sales for affiliates that are active before and after the formation of AFTA. In addition, new affiliates in ASEAN countries direct a larger share of their sales to third countries than new affiliates elsewhere in Asia. These findings are consistent the Polity2 variable in Marshall and Jaggers (2009). 
with the model's predictions.

Our results have significant implications for the welfare effects of regional trade agreements. Increased multinational firm activity in a regional free trade area is likely to generate benefits within the region as multinationals typically exhibit high levels of productivity, pay high wages, and create positive spillovers for other firms. Policy makers from excluded countries have reason to support the creation of regional trade agreements because firms from excluded countries can benefit through the use of foreign direct investment.

The findings also point out the relevance of incorporating firm level heterogeneity into models of multinational firms. Only recently have these theories been confronted with firm-level data that allow for a careful analysis of intensive and extensive responses to shifts in environmental factors. 


\section{A Appendix}

In this Appendix we briefly discuss the effects of the regional trade agreement in the model for the case in which the distribution of productivity $G(\varphi)$ is Pareto, so that

$$
G(\varphi)=1-\left(\frac{b}{\varphi}\right)^{k}
$$

with $k>\sigma-1$, a condition needed for the distribution of sale revenue to have finite variance. Given our results in the model, Western parents with productivity lower than $\varphi_{X}^{*}$ have no affiliates in the South-East area, those with productivity between $\varphi_{X}^{*}$ and $\varphi_{I}^{*}{ }_{E S}$ have one affiliate, and those with productivity higher than $\varphi_{I}^{*}{ }_{E S}$ have two. Normalizing the total measure of U.S. firms to 1, we have that the measure of affiliates in the South-East area is given by

$$
\begin{aligned}
n & =G\left(\varphi_{I_{-} E S}^{*}\right)-G\left(\varphi_{X}^{*}\right)+2\left(1-G\left(\varphi_{I_{-} E S}^{*}\right)\right)=2-\left(G\left(\varphi_{X}^{*}\right)+G\left(\varphi_{I_{-} E S}^{*}\right)\right) \\
& =\left(\frac{b}{\varphi_{I_{-} E S}^{*}}\right)^{k}+\left(\frac{b}{\varphi_{X}^{*}}\right)^{k} .
\end{aligned}
$$

It then follows that

$$
\frac{\partial n}{\partial \underline{\tau}}=-k b^{k}\left[\left(\varphi_{I_{-} E S}^{*}\right)^{-k-1} \frac{\partial \varphi_{I_{-} E S}^{*}}{\partial \underline{\tau}}+\left(\varphi_{X}^{*}\right)^{-k-1} \frac{\partial \varphi_{X}^{*}}{\partial \underline{\tau}}\right]
$$

which at first sight appears ambiguous since $\partial \varphi_{X}^{*} / \partial \underline{\tau}>0$ but $\partial \varphi_{I_{-} E S}^{*} / \partial \underline{\tau}<0$. Using the definitions of $\varphi_{X}^{*}$ and $\varphi_{I_{-} E S}^{*}$, that is,

$$
\varphi_{X}^{*}=\left(\frac{f}{\psi^{I-E}-\psi^{X}}\right)^{1 /(\sigma-1)}
$$

and

$$
\varphi_{I_{-} E S}^{*}=\left(\frac{f}{\psi^{I_{-} E S}-\psi^{I_{-} E}}\right)^{1 /(\sigma-1)},
$$

we find however that

$$
\frac{\frac{\partial \varphi_{X}^{*}}{\partial \underline{\tau}}}{\frac{\partial \varphi_{I_{-} E S}^{*}}{\partial \underline{\tau}}}=-\left(\frac{\varphi_{X}^{*}}{\varphi_{I_{-} E S}^{*}}\right)^{\sigma}
$$

and thus

$$
\frac{\partial n}{\partial \underline{\tau}}=k b^{k} \frac{\frac{\partial \varphi_{I_{-} E S}^{*}}{\partial \underline{\tau}}}{\left(\varphi_{I_{-} E S}^{*}\right)^{\sigma}}\left[\left(\varphi_{X}^{*}\right)^{-(k-(\sigma-1))}-\left(\varphi_{I_{-} E S}^{*}\right)^{-(k-(\sigma-1))}\right]<0,
$$

which is negative because $\partial \varphi_{I_{-} E S}^{*} / \partial \underline{\tau}<0, k>\sigma-1$, and $\varphi_{I_{-} E S}^{*}>\varphi_{X}^{*}$.

We next study the effect of the agreement on aggregate affiliate sales. Aggregate sales of 
Western multinationals with one affiliate are given by

$$
\begin{aligned}
R^{I_{-} E} & =\int_{\varphi_{X}^{*}}^{\varphi_{I_{-}}^{*} E S} \sigma \psi^{I_{-} E} \varphi^{\sigma-1} d G(\varphi) \\
& =\sigma \psi^{I_{-} E} \int_{\varphi_{X}^{*}}^{\varphi_{I_{-} E S}^{*}} \varphi^{\sigma-1} k b^{k} \varphi^{-k-1} d \varphi \\
& =\sigma \psi^{I_{-} E} \frac{k b^{k}}{k-(\sigma-1)}\left[\left(\varphi_{X}^{*}\right)^{-(k-(\sigma-1))}-\left(\varphi_{I_{-} E S}^{*}\right)^{-(k-(\sigma-1))}\right]
\end{aligned}
$$

On the other hand, aggregate sales of affiliates of Western multinational firms with two affiliates are given by:

$$
\begin{aligned}
R_{-}^{I_{-} E S} & =\int_{\varphi_{I_{-} E S}^{*}}^{\infty} \sigma \psi^{I_{-} E S} \varphi^{\sigma-1} d G(\varphi) \\
& =\sigma \psi^{I_{-} E S} \int_{\varphi_{X}^{*}}^{\infty} \varphi^{\sigma-1} k b^{k} \varphi^{-k-1} d \varphi \\
& =\sigma \psi^{I_{-} E S} \frac{k b^{k}}{k-(\sigma-1)}\left(\varphi_{I_{-} E S}^{*}\right)^{-(k-(\sigma-1))}
\end{aligned}
$$

Aggregate affiliate sales are then given by

$$
R=\Theta\left\{\psi^{I_{-} E} \cdot\left(\varphi_{X}^{*}\right)^{-(k-(\sigma-1))}+\left(\psi^{I_{-} E S}-\psi^{I_{-} E}\right) \cdot\left(\varphi_{I_{-} E S}^{*}\right)^{-(k-(\sigma-1))}\right\},
$$

where $\Theta$ is a constant. Using (A1) and (A2), we can write this expression as

$$
R=\Theta\left\{\psi^{I_{-} X} \cdot\left(\varphi_{X}^{*}\right)^{-(k-(\sigma-1))}+f \cdot\left(\varphi_{X}^{*}\right)^{-k}+f \cdot\left(\varphi_{I_{-} E S}^{*}\right)^{-k}\right\} .
$$

But note that $\psi^{I_{-} X}$ is independent of $\underline{\tau},\left(\varphi_{X}^{*}\right)^{-(k-(\sigma-1))}$ is decreasing in $\underline{\tau}$ (for $k>\sigma-1$ ), while in our derivations regarding the number of affiliates above, we have shown that $\left(\varphi_{X}^{*}\right)^{-k}+$ $\left(\varphi_{I_{-} E S}^{*}\right)^{-k}$ is also decreasing in $\underline{\tau}$. Hence, we can conclude that when productivity follows a Pareto distribution, a regional trade agreement between the South and the East (i.e., a fall in $\underline{\tau})$ increases affiliate sales in the area. 


\section{References}

Aitken, B., G. Hanson and A.E. Harrison (1996), "Wages and Foreign Ownership: A Comparative Study of Mexico, Venezuela, and the United States", Journal of International Economics, Vol. 40, Issue 3-4, pp. 345-371.

Aitken, B. and A. Harrison (1999), "Do Domestic Firms Benefit from Foreign Direct Investment? Evidence from Panel Data," American Economic Review, 89(3), pp. 605-618.

Antràs, Pol and Elhanan Helpman (2004), "Global Sourcing," Journal of Political Economy, 112:3, pp. 552-580.

Brainard, S. Lael (1997), "An Empirical Assessment of the Proximity-Concentration Trade-off Between Multinational Sales and Trade," American Economic Review, 87:4, pp. 520-544.

Caves, Richard E. (1996), Multinational Enterprise and Economic Analysis, Second Edition, Cambridge University Press.

Chen, Maggie (2008), "Regional Economic Integration and Geographic Concentration of Multinational Firms," European Economic Review, forthcoming.

Desai, Mihir A., C. Fritz Foley, and James R. Hines Jr. (2008), "Domestic Effects of the Foreign Activities of U.S. Multinationals," forthcoming in American Economic Journal: Economic Policy.

Ekholm, Karolina, Rikard Forslid and James R. Markusen (2007), "Export-Platform Foreign Direct Investment," Journal of the European Economic Association, Vol. 5, No. 4, Pages 776-795.

Grossman, Gene, Elhanan Helpman and Adam Szeidl (2006), "Optimal Integration Strategies for the Multinational Firm," Journal of International Economics, vol. 70, September, pp. 216-238.

Haskel, Jonathan E., Sonia Pereira and Matthew Slaughter (2007), "Does Inward Foreign Direct Investment Boost the Productivity of Domestic Firms?," Review of Economics and Statistics, Vol. 89, No. 3: 482-496.

Helpman, Elhanan (1984), "A Simple Theory of International Trade with Multinational Corporations", Journal of Political Economy, 92:3, pp. 451-471.

Helpman, Elhanan, Marc J. Melitz, and Stephen R. Yeaple (2004), "Export versus FDI with Heterogeneous Firms," American Economic Review 94:1, pp.300-316.

Heyman, F., F. Sjöholm and P. Gustavsson Tingvall (2007), "Is there Really a Foreign Ownership Wage Premium? Evidence from Matched Employer-Employee Data (2007), Journal of International Economics, Vol. 73 (2), pp. 355-376.

Krugman, Paul, and Anthony Venables (1996), "Integration, Specialization, and Adjustment," European Economic Review 40:3-5, pp. 959-967. 
Krueger, Anne O. (1999), "Are Preferential Trading Arrangements Trade-Liberalizing or Protectionist?" The Journal of Economic Perspectives 13:4, pp.105-124.

Markusen, James R. (1984), "Multinationals, Multi-Plant Economies, and the Gains from Trade," Journal of International Economics, 16:3-4, pp. 205-226.

Markusen, James R. and Anthony J. Venables (2000), "The Theory of Endowment, Intraindustry and Multi-national Trade," Journal of International Economics, 52:2, pp. 209234.

Markusen, James R. (2002), Multinational Firms and the Theory of International Trade, Cambridge, MA: MIT Press.

Marshall, Monty G. and Keith Jaggers. (1999), Polity IV Project, dataset available at: http://www.systemicpeace.org/polity/polity4.htm.

Motta, Massimo, and George Norman (1996), "Does Economic Integration Cause Foreign Direct Investment?" International Economic Review 37:4, pp.757-783.

Nocke, Volker, and Stephen R. Yeaple (2008), "An Assignment Theory of Foreign Direct Investment," Review of Economic Studies, 75:2, pp. 529-557.

Puga, Diego and Anthony J. Venables (1997), "Preferential Trading Agreements and Industrial Location," Journal of International Economics, 43, pp. 347-358.

Shatz, Howard J. (2000), "The Location of U.S. Multinational Affiliates," Ph.D. dissertation, Harvard University.

Smarzynska, Beata (2004), "Does Foreign Direct Investment Increase the Productivity of Domestic Firms? In Search of Spillovers through Backward Linkages," American Economic Review, 94(3), pp. 605-627.

Viner, Jacob (1950), The Customs Union Issue, New York: Carnegie Endowment for International Peace.

Yeaple, Stephen (2003), "The Complex Integration Strategies of Multinationals and Cross Country Dependencies in the Structure of FDI," Journal of International Economics, 60, pp. 293-314.

Yeaple, Stephen R. (2008a), "Firm Heterogeneity and the Structure of U.S. Multinational Activity: An Empirical Analysis," NBER Working Paper \#14072.

Yeaple, Stephen R. (2008b), "Firm Heterogeneity, Central Locations, and the Structure of Foreign Direct Investment," in E. Helpman, D. Marin, and T. Verdier (eds.), The Organization of Firms in a Global Economy, Harvard University Press, pp. 602-611. 


\section{Table 1}

\section{Effects on Aggregate Activity}

This table presents measures of U.S. multinational aggregate activity in ASEAN and other Asian countries in 1989 and 1994. The sample includes nonbank affiliates that filed long or short survey forms. Number of Affiliates and Number of Parents are, respectively, the number of U.S. MNE affiliates and parents operating in the region. Net PPE measures the net property, plant, and equipment of MNE affiliates. Growth rates are computed by taking the difference between 1994 and 1989 values and dividing by 1989 values.

$1989 \quad 1994 \quad$ Growth Rate

\section{ASEAN Countries}

Number of Affiliates 740

309

1,065

$44 \%$

Number of Parents

$36,939,740$

403

$30 \%$

Aggregate Sales

$28,103,986$

$83,218,640$

$125 \%$

Aggregate Assets

$2,216,711$

$68,206,904$

$143 \%$

Aggregate Employment Compensation

$11,903,194$

$5,346,706$

$141 \%$

Aggregate Net PPE

$27,964,768$

$135 \%$

Other Asian Countries

Number of Affiliates

Number of Parents

$$
2,417
$$

$$
3,052
$$

$26 \%$

Aggregate Sales

Aggregate Assets

$233,633,360$

$308,670,176$

$32 \%$

Aggregate Employment Compensation

$171,856,768$

$258,032,128$

$50 \%$

Aggregate Net PPE

$25,960,936$

$37,153,888$

$43 \%$

$59,890,208$

$92,479,056$

$54 \%$ 
Table 2

\section{Effects on Aggregate Activity: Intensive Margin}

This table presents measures of U.S. multinational aggregate activity in ASEAN and other Asian countries in 1989 and 1994 for affiliates that report activity in both years. The sample includes nonbank affiliates that filed long or short survey forms. Number of Affiliates is the number of U.S. MNE affiliates operating in the region. Net PPE measures the net property, plant, and equipment of MNE affiliates. Growth rates are computed by taking the difference between 1994 and 1989 values and dividing by 1989 values.

$1989 \quad 1994 \quad$ Growth Rate

ASEAN Countries

Number of Affiliates

Aggregate Sales

$\begin{array}{rrr}507 & 507 & 0 \% \\ 31,365,546 & 67,467,664 & 115 \% \\ 22,387,278 & 49,965,720 & 123 \% \\ 1,806,404 & 3,898,378 & 116 \% \\ 9,720,393 & 19,589,564 & 102 \%\end{array}$

Other Asian Countries

Number of Affiliates

$$
1,591
$$

1,591

$0 \%$

Aggregate Sales

$181,131,168 \quad 256,260,880$

$41 \%$

Aggregate Assets

$131,140,912$

$201,230,736$

$53 \%$

Aggregate Employment Compensation

$20,550,656 \quad 30,694,388$

$49 \%$

Aggregate Net PPE

$46,193,692$

$69,387,904$

$50 \%$ 


\section{Table 3}

\section{Effects on Aggregate Activity: Extensive Margin}

This table presents measures of U.S. multinational aggregate activity in ASEAN and other Asian countries in 1989 and 1994 for affiliates that report activity only in either 1989 or 1994 . The sample includes nonbank affiliates that filed long or short survey forms. The first column provides 1989 aggregates for affiliates that exit the sample after 1989 and before 1994, and the second column provides 1994 aggregates for affiliates that enter the sample after 1989 and before 1994. Number of Affiliates is the number of U.S. MNE affiliates operating in the region. Net PPE measures the net property, plant, and equipment of MNE affiliates.

\section{Exiting Affiliate Entering Affiliate 1989 Activity 1994 Activity}

ASEAN Countries

Number of Affiliates

Aggregate Sales

$5,574,194$

$15,750,973$

Aggregate Assets

$5,716,708$

$18,241,180$

Aggregate Employment Compensation

410,307

$1,448,328$

Aggregate Net PPE

$2,182,801$

$8,375,202$

Other Asian Countries

Number of Affiliates

Aggregate Sales

$52,502,180$

$52,409,312$

Aggregate Assets

$40,715,852$

$56,801,392$

Aggregate Employment Compensation 


\section{Table 4}

\section{Effects on Aggregate Sales Patterns}

This table presents information on the direction of sales of affiliates in ASEAN and other Asian countries. The sample includes majority-owned nonbank affiliates that filed long or short survey forms. The top panel presents data on the activities of all affiliates, the second panel presents data only on those affiliates that appear in both the 1989 and 1994 samples, and the bottom panel presents data on affiliates that exit and enter the sample between 1989 and 1994. In order to avoid the potential disclosure of confidential information, the top panel was constructed using published data that do not include figures for Brunei, but the other panels cover all ASEAN countries. In the bottom panel, the first column provides 1989 figures for affiliates that appear in the 1989 sample but not in the 1994 sample, and the second column provides 1994 figures for affiliates that appear in the 1994 sample but not the 1989 sample. Share of Sales to the Host Country Market measures the ratio of sales to persons in the affiliates host country to affiliate total sales. Share of Sales to the U.S. and Share of Sales to Third Countries respectively measure the share of sales to person in the U.S. and to countries other than the U.S. and the affiliate's host country.

\begin{tabular}{lrr}
\hline Panel A: All Affiliate Activity & 1989 & 1994 \\
\hline \multicolumn{1}{c}{ ASEAN Countries } & & \\
Share of Sales to the Host Country Market & $45.8 \%$ & $47.1 \%$ \\
Share of Sales to the U.S. & $25.9 \%$ & $20.4 \%$ \\
Share of Sales to Third Countries & $28.3 \%$ & $32.5 \%$
\end{tabular}

\section{Other Asian Countries}

Share of Sales to the Host Country Market

$78.6 \%$

$83.1 \%$

Share of Sales to the U.S.

$8.6 \%$

$5.7 \%$

Share of Sales to Third Countries

$12.8 \%$

$11.2 \%$

\section{Panel B: Surviving Affiliates}

\section{ASEAN Countries}

Share of Sales to the Host Country Market

Share of Sales to the U.S.

Share of Sales to Third Countries

\section{Other Asian Countries}

Share of Sales to the Host Country Market

Share of Sales to the U.S.

$79.9 \%$

$81.5 \%$

Share of Sales to Third Countries
1989

1994

$\longrightarrow$

Panel C: Entrants and Exits

Exiting Affiliates 1989 Entering Affiliate 1994

\section{ASEAN Countries}

Share of Sales to the Host Country Market Activity Activity

Share of Sales to the U.S.

\section{Other Asian Countries}

Share of Sales to the Host Country Market 
Table 5

\section{Descriptive Statistics}

This table provides descriptive statistics for the variables used in the regression analysis. The top panel diplays measures of affiliate activity that are used in the analysis presetned in Tables 6 and 8. Growth rates of sales, assets, employment compensation and net property plant and equipment are measured by taking the difference between end and beginning of period values and dividing by the average of end and beginning of period values. Growth in sales due to sales to a particular location are computed by taking the difference between end and beginning of period values of sales to that location and dividing by the average of end and beginning of period values of total sales. The second panel displays country/industry measures of growth used in the analysis presnted in Table 7. The third panel displays affiliate measures of the direction of affiliate sales in 1994 used in the analysis presented in Table 9. Data on the direction of sales are only reported by majority-owned affiliates.

Mean Deviation

Affiliate Measures of Growth

Sales Growth $\quad 0.4052$

0.6670

Asset Growth

0.4178

0.6003

Employment Compensation Growth

0.4778

0.7102

Net PPE Growth

0.3222

0.8691

Growth in Sales due to Local Sales

0.2920

0.5906

Growth in Sales due to U.S. Sales

0.0185

0.2839

Growth in Sales due to Third Country Sales

0.0824

0.3700

Country/Industry Measures of Growth

Sales Growth

0.4780

0.8052

Asset Growth

0.5092

0.8017

Employment Compensation Growth

0.5203

0.8329

Net PPE Growth

0.4941

0.9513

Direction of Sales

Share of Sales to Local Market

0.7894

0.3519

Share of Sales to U.S.

0.0709

0.2201

Share of Sales to Third Countries

0.1397

0.2790

Controls

Per Capita GDP Growth

0.1583

0.1430

Changes in Tax Rate

$-0.0298$

0.0390

Log of per capita GDP

9.3365

1.3979

Tax Rate

0.3146

0.1249 


\section{Table 6}

\section{Affiliate Level Responses}

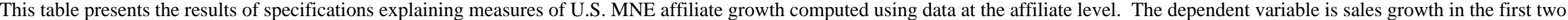

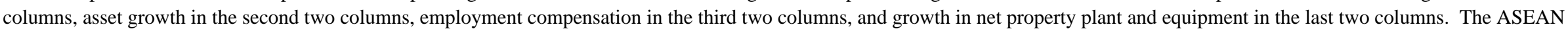

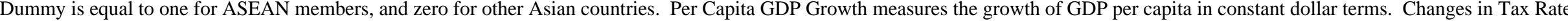

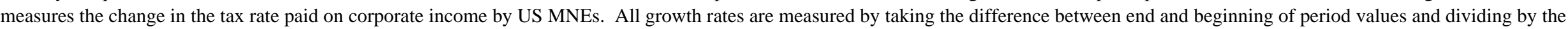
average of end and beginning of period values. Heteroskedasticity-consistent standard errors that allow for clustering by country appear in parentheses.

\begin{tabular}{|c|c|c|c|c|c|c|c|c|}
\hline \multirow[t]{2}{*}{ Dependent Variable: } & \multicolumn{2}{|c|}{ Sales Growth } & \multicolumn{2}{|c|}{ Asset Growth } & \multicolumn{2}{|c|}{$\begin{array}{c}\text { Employment Compensation } \\
\text { Growth }\end{array}$} & \multicolumn{2}{|c|}{ Net PPE Growth } \\
\hline & $(1)$ & $(2)$ & $(3)$ & (4) & $(5)$ & $(6)$ & $(7)$ & $(8)$ \\
\hline ASEAN Dummy & $\begin{array}{r}0.1638 \\
(0.0630)\end{array}$ & $\begin{array}{r}0.0842 \\
(0.0383)\end{array}$ & $\begin{array}{r}0.2014 \\
(0.0601)\end{array}$ & $\begin{array}{r}0.1829 \\
(0.0546)\end{array}$ & $\begin{array}{r}0.2118 \\
(0.0961)\end{array}$ & $\begin{array}{r}0.1380 \\
(0.0737)\end{array}$ & $\begin{array}{r}0.1520 \\
(0.1009)\end{array}$ & $\begin{array}{r}0.1738 \\
(0.0853)\end{array}$ \\
\hline $\begin{array}{l}\text { Per Capita GDP } \\
\text { Growth }\end{array}$ & & $\begin{array}{r}0.6323 \\
(0.1941)\end{array}$ & & $\begin{array}{r}0.1634 \\
(0.2064)\end{array}$ & & $\begin{array}{r}0.6064 \\
(0.3133)\end{array}$ & & $\begin{array}{l}-0.1468 \\
(0.1760)\end{array}$ \\
\hline Changes in Tax Rate & & $\begin{array}{r}0.9047 \\
(0.8479)\end{array}$ & & $\begin{array}{r}0.6883 \\
(0.7199)\end{array}$ & & $\begin{array}{r}1.0420 \\
(1.0668)\end{array}$ & & $\begin{array}{r}0.5478 \\
(1.2317)\end{array}$ \\
\hline Constant & $\begin{array}{r}0.3654 \\
(0.0486)\end{array}$ & $\begin{array}{r}0.3116 \\
(0.0627)\end{array}$ & $\begin{array}{r}0.3690 \\
(0.0503)\end{array}$ & $\begin{array}{r}0.3681 \\
(0.0617)\end{array}$ & $\begin{array}{r}0.4274 \\
(0.0800)\end{array}$ & $\begin{array}{r}0.3806 \\
(0.0962)\end{array}$ & $\begin{array}{r}0.2853 \\
(0.0814)\end{array}$ & $\begin{array}{r}0.3195 \\
(0.1001)\end{array}$ \\
\hline $\begin{array}{l}\text { No. of Obs. } \\
\text { R-Squared }\end{array}$ & $\begin{array}{l}2,090 \\
0.011 \\
\end{array}$ & $\begin{array}{l}2,090 \\
0.034 \\
\end{array}$ & $\begin{array}{l}2,090 \\
0.021 \\
\end{array}$ & $\begin{array}{l}2,090 \\
0.025 \\
\end{array}$ & $\begin{array}{l}2,023 \\
0.016 \\
\end{array}$ & $\begin{array}{l}2,023 \\
0.035 \\
\end{array}$ & $\begin{array}{l}2,068 \\
0.006 \\
\end{array}$ & $\begin{array}{l}2,068 \\
0.006\end{array}$ \\
\hline
\end{tabular}


Table 7

\section{Country/Industry Level Responses}

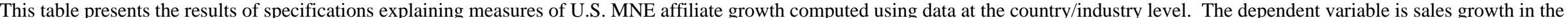

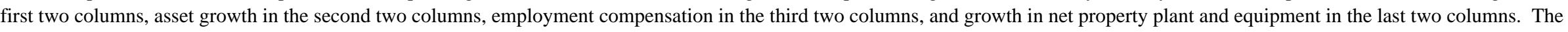

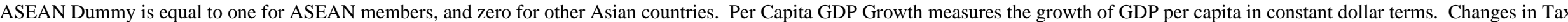

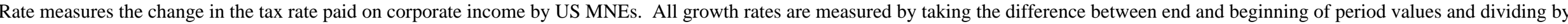
the average of end and beginning of period values. Heteroskedasticity-consistent standard errors that allow for clustering by country appear in parentheses.

\begin{tabular}{|c|c|c|c|c|c|c|c|c|}
\hline \multirow[t]{2}{*}{ Dependent Variable: } & \multicolumn{2}{|c|}{ Sales Growth } & \multicolumn{2}{|c|}{ Asset Growth } & \multicolumn{2}{|c|}{$\begin{array}{c}\text { Employment Compensation } \\
\text { Growth }\end{array}$} & \multicolumn{2}{|c|}{ Net PPE Growth } \\
\hline & $(1)$ & $(2)$ & (3) & $(4)$ & $(5)$ & (6) & $(7)$ & $(8)$ \\
\hline ASEAN Dummy & $\begin{array}{r}0.2214 \\
(0.1125)\end{array}$ & $\begin{array}{r}0.1213 \\
(0.0914)\end{array}$ & $\begin{array}{r}0.2530 \\
(0.0759)\end{array}$ & $\begin{array}{r}0.2178 \\
(0.0857)\end{array}$ & $\begin{array}{r}0.3085 \\
(0.1100)\end{array}$ & $\begin{array}{r}0.2082 \\
(0.0850)\end{array}$ & $\begin{array}{r}0.3027 \\
(0.0941)\end{array}$ & $\begin{array}{r}0.3095 \\
(0.1079)\end{array}$ \\
\hline $\begin{array}{l}\text { Per Capita GDP } \\
\text { Growth }\end{array}$ & & $\begin{array}{r}1.1134 \\
(0.4337)\end{array}$ & & $\begin{array}{r}0.4645 \\
(0.4094)\end{array}$ & & $\begin{array}{r}1.2034 \\
(0.3575)\end{array}$ & & $\begin{array}{r}0.0999 \\
(0.4875)\end{array}$ \\
\hline Changes in Tax Rate & & $\begin{array}{l}-0.0679 \\
(1.2377)\end{array}$ & & $\begin{array}{r}0.3763 \\
(1.1181)\end{array}$ & & $\begin{array}{r}0.5470 \\
(0.9244)\end{array}$ & & $\begin{array}{r}0.9626 \\
(1.5739)\end{array}$ \\
\hline Constant & $\begin{array}{r}0.4071 \\
(0.0690)\end{array}$ & $\begin{array}{r}0.2285 \\
(0.0609)\end{array}$ & $\begin{array}{r}0.4282 \\
(0.0602)\end{array}$ & $\begin{array}{r}0.3610 \\
(0.0553)\end{array}$ & $\begin{array}{r}0.4215 \\
(0.0745)\end{array}$ & $\begin{array}{r}0.2395 \\
(0.0591)\end{array}$ & $\begin{array}{r}0.3975 \\
(0.0830)\end{array}$ & $\begin{array}{r}0.3991 \\
(0.0887)\end{array}$ \\
\hline $\begin{array}{l}\text { No. of Obs. } \\
\text { R-Squared }\end{array}$ & $\begin{array}{r}665 \\
0.017\end{array}$ & $\begin{array}{r}665 \\
0.044\end{array}$ & $\begin{array}{r}665 \\
0.022\end{array}$ & $\begin{array}{r}665 \\
0.028\end{array}$ & $\begin{array}{r}662 \\
0.030\end{array}$ & $\begin{array}{r}662 \\
0.065\end{array}$ & $\begin{array}{r}664 \\
0.022\end{array}$ & $\begin{array}{r}664 \\
0.025\end{array}$ \\
\hline
\end{tabular}




\section{Table 8}

\section{Decomposition of Sales Growth}

This table presents the results of specifications explaining components of the growth of U.S. MNE affiliates measured using data at the affiliate level. The dependent variable is growth in sales due to local sales in the first two columns, the growth in sales due to sales to the U.S. in the second two columns, and the growth in sales due to sales to countries other than the U.S. and the affiliate's host country in the last two columns. The ASEAN Dummy is equal to one for ASEAN members, and zero for other Asian countries. The Dummy if in One ASEAN

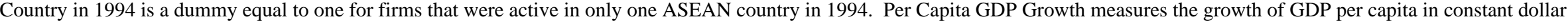

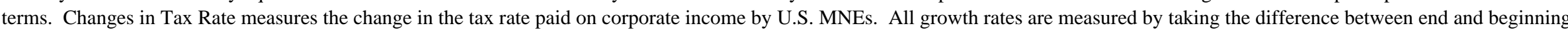

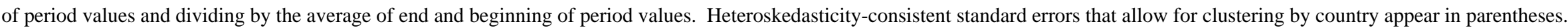

\begin{tabular}{|c|c|c|c|c|c|c|}
\hline \multirow[t]{2}{*}{ Dependent Variable: } & \multicolumn{2}{|c|}{$\begin{array}{c}\text { Growth in Sales Due to Local } \\
\text { Sales }\end{array}$} & \multicolumn{2}{|c|}{$\begin{array}{c}\text { Growth in Sales Due to U.S. } \\
\text { Sales }\end{array}$} & \multicolumn{2}{|c|}{$\begin{array}{c}\text { Growth in Sales Due to Third } \\
\text { Country Sales }\end{array}$} \\
\hline & $(1)$ & $(2)$ & $(3)$ & (4) & $(5)$ & $(6)$ \\
\hline ASEAN Dummy & $\begin{array}{l}-0.0018 \\
(0.0564)\end{array}$ & $\begin{array}{r}0.0274 \\
(0.0524)\end{array}$ & $\begin{array}{r}0.0224 \\
(0.0106)\end{array}$ & $\begin{array}{r}0.0230 \\
(0.0132)\end{array}$ & $\begin{array}{r}0.0391 \\
(0.0382)\end{array}$ & $\begin{array}{r}0.0284 \\
(0.0368)\end{array}$ \\
\hline $\begin{array}{l}\text { ASEAN Dummy*Dummy if in One } \\
\text { ASEAN Country in } 1994\end{array}$ & & $\begin{array}{l}-0.1622 \\
(0.1110)\end{array}$ & & $\begin{array}{r}-0.0035 \\
(0.0317)\end{array}$ & & $\begin{array}{r}0.0593 \\
(0.0237)\end{array}$ \\
\hline Per Capita GDP Growth & $\begin{array}{r}0.5002 \\
(0.1667)\end{array}$ & $\begin{array}{r}0.5134 \\
(0.1591)\end{array}$ & $\begin{array}{r}0.0684 \\
(0.0333)\end{array}$ & $\begin{array}{r}0.0687 \\
(0.0324)\end{array}$ & $\begin{array}{r}0.1989 \\
(0.1677)\end{array}$ & $\begin{array}{r}0.1941 \\
(0.1650)\end{array}$ \\
\hline Changes in Tax Rate & $\begin{array}{r}0.6840 \\
(0.6291)\end{array}$ & $\begin{array}{r}0.6439 \\
(0.6208)\end{array}$ & $\begin{array}{r}-0.0719 \\
(0.1434)\end{array}$ & $\begin{array}{r}-0.0728 \\
(0.1424)\end{array}$ & $\begin{array}{r}0.3278 \\
(0.3479)\end{array}$ & $\begin{array}{r}0.3425 \\
(0.3420)\end{array}$ \\
\hline Constant & $\begin{array}{r}0.2327 \\
(0.0449)\end{array}$ & $\begin{array}{r}0.2299 \\
(0.0441)\end{array}$ & $\begin{array}{r}-0.0008 \\
(0.0091)\end{array}$ & $\begin{array}{r}-0.0008 \\
(0.0090)\end{array}$ & $\begin{array}{r}0.0497 \\
(0.0381)\end{array}$ & $\begin{array}{r}0.0508 \\
(0.0377)\end{array}$ \\
\hline $\begin{array}{l}\text { No. of Obs. } \\
\text { R-Squared }\end{array}$ & $\begin{array}{l}1,620 \\
0.020\end{array}$ & $\begin{array}{l}1,620 \\
0.024\end{array}$ & $\begin{array}{l}1,620 \\
0.003\end{array}$ & $\begin{array}{l}1,620 \\
0.003\end{array}$ & $\begin{array}{l}1,620 \\
0.014\end{array}$ & $\begin{array}{l}1,620 \\
0.015\end{array}$ \\
\hline
\end{tabular}


Table 9

\section{Direction of Sales of New Affiliates}

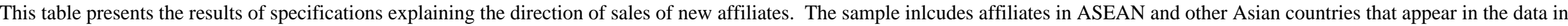

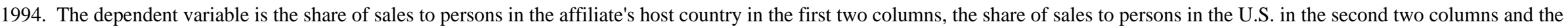

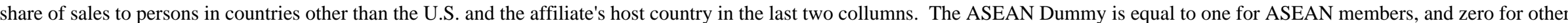

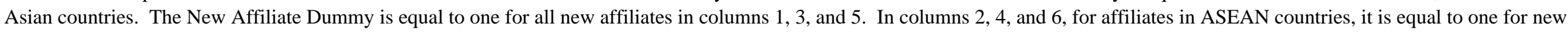

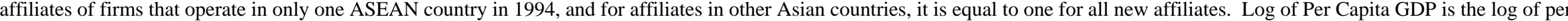
capita GDP, and Tax Rate measures the corporate income tax rate. Heteroskedasticity-consistent standard errors that allow for clustering by country appear in parentheses.

Dependent Variable:

ASEAN Dummy

New Affiliate Dummy

ASEAN Dummy*

New Affiliate Dummy

Log of Per Capita GDP

Tax Rate

Constant

In Asean countries, new affiliates include all new affiliates?

In Asean countries, new affiliates include all new affiliates of firms operating in one Asean country in 1994 ?

No. of Obs.

R-Squared
Share of Sales to Local Market

Share of Sales to U.S.

Share of Sales to Third Countries

\section{(1)}

\section{$-0.1787$}

(0.0524)

0.0314

(0.0245)

0.0216

$(0.0309)$

$-0.0388$

$(0.0125)$

0.7745
$(0.1873)$

(3)

(4)

(5)

0.1205

(0.0555)

(0.0180)

0.0319

(0.0245)

$-0.0091$

(0.0106)

$-0.1220$

(0.0812)

$-0.0121$

(0.0119)

$-0.0371$

(0.0126)

(0.1873)

0.7662
$(0.1899)$

0.9495

(0.0956)

0.9356

(0.0951)

Y

$\mathrm{N}$

0.0105

(0.0052)

-0.2061
$(0.0843)$

0.0251

(0.0422)

Y

0.0410
$(0.0193)$

(0.0419)

$-0.0093$

$-0.0223$

(0.0143)

(0.0106)

$-0.0095$

(0.0210)

(0.0497)

0.0098

(0.0054)

0.0283

(0.0104)

$-0.2026$

$-0.5684$

(0.1137)

(0.0859)

0.0310

(0.0438)

0.0254

(0.0824)

N

Y

$\mathrm{N}$

N

3,299

0.103
Y
3,299
0.103
Y

3,299
0.022

$\mathrm{N}$

(6)

0.0958

(0.0413)

$-0.0226$

(0.0143)

0.0738

(0.0371)

0.0273

(0.0103)

$-0.5636$

(0.1148)

0.0333

(0.0815)

Y 3,299 0.083 